\title{
Plant biotechnology for food security and bioeconomy
}

\author{
Jihong Liu Clarke • Peng Zhang
}

Published online: 17 July 2013

(C) Springer Science+Business Media Dordrecht 2013

\begin{abstract}
This year is a special year for plant biotechnology. It was 30 years ago, on January 18 1983, one of the most important dates in the history of plant biotechnology, that three independent groups described Agrobacterium tumefaciensmediated genetic transformation at the Miami Winter Symposium, leading to the production of normal, fertile transgenic plants (Bevan et al. in Nature 304:184-187, 1983; Fraley et al. in Proc Natl Acad Sci USA 80:4803-4807, 1983; HerreraEstrella et al. in EMBO J 2:987-995, 1983; Vasil in Plant Cell Rep 27:1432-1440, 2008). Since then, plant biotechnology has rapidly advanced into a useful and valuable tool and has made a significant impact on crop production, development of a biotech industry and the bio-based economy worldwide.
\end{abstract}

Keywords Plant biotechnology $\cdot$ GM crops $\cdot$ Food production $\cdot$ Bioeconomy

\section{Plant biotechnology—where are we after a 30-year journey?}

Global utilization of genetically modified (GM) crops

Since the production of the first transgenic plants 30 years ago and following the first planting of GM crops in 1996,

\section{J. L. Clarke (ه)}

Bioforsk-Norwegian Institute for Agricultural and

Environmental Research, Høgskoleveien 7,

$1430 \AA$ Ås, Norway

e-mail: jihong.liu-clarke@bioforsk.no

\section{P. Zhang}

SIBS-ETH Shanghai Center for Cassava Biotechnology, Institute of Plant Physiology and Ecology, SIBS, Chinese Academy of Sciences, 300 Fenglin Road, Shanghai 200032, China plant biotechnology has had an increasingly significant role in modern agriculture. Globally, the cultivation of GM crops increased 100-fold, from 1.7 million hectares in 1996, to 170 million hectares in 2012 (James 2012) demonstrating the potential of plant biotechnology. In 2012, a record 17.3 million farmers in 30 countries grew GM crops, with an increase of 0.6 million farmers compared to 2011. Of these, over $90 \%$ (i.e. over 15 million), were small resource-poor farmers in developing countries. To date, developing countries grow more GM crops than industrial countries (52 vs. $48 \%$ in 2012), indicating the benefits of GM crops to farmers worldwide. Five European countries (Spain, Portugal, the Czech Republic, Slovakia and Romania) have planted a record 129,071 hectares of GM Bt maize, a $13 \%$ increase over 2011, despite the extensive debate about GM crops, the strong anti-GM trend in Europe, and the regulatory constraints. Facing the challenge of a world population that is expected to reach an estimated 9 billion in 2050, food production globally has to increase by about $70 \%$ in order to feed the world. The difficulty in managing this daunting task is that we have to produce more food with less arable land. Moreover, climate change adds yet another challenge to food security (FAO High Level Expert Forum; Rome 12-13 October 2009, http://www.fao.org). In order to feed the world in 2050, plant biotechnological advances in modern agriculture are essential. After 30 years of plant biotechnology with many convincing successes for GM crops, people living in wealthy and developing countries, and irrespective of their attitude towards GM crops, agree upon one issue: it is everyone's business to secure food production for the world's growing population and to save the lives of the one billion people (mostly children) who do not have enough food to survive! Good examples are China, India, Brazil, Argentina and South Africa. They grow about $46 \%$ of 
global GM crops, and have $\sim 40 \%$ of the world population (see detailed information provided by www.isaaa.org).

Biotech crops with added value (bio-fortification)

There are numerous examples that have been described and reviewed. Here, a couple of landmark examples will be mentioned. In the millennium year 2000, Golden Rice (GR), a GM rice rich in $\beta$-carotene for use as a source of vitamin A was first reported. Dietary micronutrient deficiencies, such as the lack of vitamin A, iodine, iron or zinc, are major causes of illness and mortality worldwide. These deficiencies affect particularly children, impairing their immune system and normal development, causing disease and ultimately death (www.goldenrice.org). The best way to avoid micronutrient deficiencies is by way of a varied diet, rich in vegetables, fruits and animal products. Rice produces $\beta$-carotene in the leaves but not in the grain, where the biosynthetic pathway is turned off during plant development. In Golden Rice two genes have been inserted into the rice genome by genetic engineering to restart the carotenoid biosynthetic pathway, leading to the production and accumulation of $\beta$-carotene in the grains. Both genes are naturally required for carotene biosynthesis. The difference here is that the reconstructed pathway is not subject to down-regulation, as usually happens in grain (www.goldenrice.org). The $\beta$-Carotene in Golden Rice is as good as $\beta$-carotene in oil in providing vitamin $A$ to children (Tang et al. 2012). Similarly, it is known that consumption of anthocyanin-rich food promotes health. Many recent studies of anthocyanin-rich fruits such as blueberry, bilberry and cranberry support claims that anthocyanin consumption promotes health. Purple GM tomatoes with enhanced anthocyanin accumulation have been produced and animal studies have proven its health value (Martin et al. 2011; Glover and Martin 2012).

\section{Contribution of plant biotechnology to the bio-based economy}

Over the past decades biotechnology has served as an engineer for environmentally-friendly production of various products including the GM crops described above, health products, biofuels etc. and contributed significantly to the bio-based economy. Economic benefits have been the driving force of farmers worldwide to grow GM crops. At the farm level more than US\$98 billion were generated globally by GM crops during the 16-year period 1996-2011, of which $51 \%$ were due to reduced production costs (less ploughing, fewer pesticide sprays, and less labour) and $49 \%$ due to substantial yield gains of 328 million tons. The corresponding figures for 2011 alone were $78 \%$ of the total gain due to increased yield (equivalent to 50.2 million tons), and $22 \%$ due to lower cost of production (Brookes and Barfoot 2013). Bt cotton increased the income of farmers significantly by up to US $\$ 250$ per hectare and also halved the number of insecticide sprays, thus reducing farmer exposure to pesticides (James 2012). According to the OECD, biotechnology-based drugs today provide greater health benefits than their traditional counterparts. By 2015, many new drugs, about half of the global production of the world's most important food plants, and a growing number of everyday items (such as food additives, plastics, fuels and detergents) will be produced using biotechnology (www.oecd.org, news 08.06.2009). Biotechnology is the most important key to opening the door to the bioeconomy, and also the essential "bridge" that connects the raw materials and the economy. Biotechnology thus plays a crucial role in the bioeconomy by assuring sustainable production and conversion of biomass to food, health and fibre products, as well as industrial products and energy.

\section{Growing medicines and enzymes in GM plants}

Plant biotechnology has served as an effective instrument for genetic engineering of plants for cost effective production of medicines. Despite regulatory difficulties, a number of GM plant-produced drugs have reached the market. A plant-produced veterinary vaccine against Newcastle disease in poultry was approved in 2006 by US Department of Agriculture Center for Veterinary Biologics (www.thepoultrysite.com; Joensuu et al. 2008; Yusibov et al. 2011). Recently, a successful plant-derived drug for humans was also approved: glucocerebrosidase enzyme replacement therapy (ERT) for the long-term treatment of adult patients with type 1 Gaucher's disease was generated through its ProCellEx ${ }^{\circledR}$ manufacturing platform, which uses genetically engineered carrot cells (http://www.genen gnews.com/gen-news-highlights/). A full list of plant derived medicines that have either entered into clinical trials or are waiting for approval by authorities can be found in the review by Yusibov et al. (2011). Low-cost production of cell wall-degrading enzymes for cost effective conversion of plant- and forest-based biomass to biofuels has demonstrated yet another important application of plant biotechnology during recent years. A number of research reports have served as "showcases" to demonstrate the potential (see publications in Plant Biotechnology Journal Special Issue on Biofuels Vol. 8(3) 243-375, 2010).

Regulatory constraints and public concern

Despite the mounting evidence showing the importance of GM plants in food, feed, health industries and the 
bioeconomy, GM plants experience strong opposition worldwide, more than any other modern technology has encountered. GM crops and products in particular are met by regulatory constraints and must cope with a long process for approval in many countries, especially in Europe. The public in Europe is polarized when talking about GM plants, regardless of the numerous small- and large-scale biosafety and risk assessment studies that have been carried out in the past two decades and shown convincing benefits of GM crops.

A timely special issue on plant biotechnology for food security and bioeconomy

On the occasion of the 30 years anniversary of plant biotechnology, which has been accompanied by many successful products and technological advances, but also by continued public scepticism and regulatory constraints, Plant Molecular Biology publishes a special issue on "Plant Biotechnology for Food Security and Bioeconomy". This special issue offers a selection of fifteen invited and peerreviewed original research highlights and reviews covering the current status of plant biotechnology and its application ranging from production of GM crops to secure food supply, metabolic engineering for health and better quality food, genetic engineering of various food and non-food crops for the bio-based economy, and technological advancement, to the history of plant biotechnology and regulatory constraints. Together with the recently released special issue of the Plant Biotechnology Journal on Next Generation Sequence Technology (Vol. 10(6) 621-759, 2012), the Plant Molecular Biology special issue provides readers with a "the state of the art" view of current advancements in plant biotechnology and an outlook for the years ahead.

Finally, we gratefully acknowledge the contributions of all authors and manuscript reviewers. We also acknowledge the help of the Editor-in-Chief and the Editorial Office staff of Plant Molecular Biology in facilitating this Special Issue on Plant Biotechnology for food security and bioeconomy.

\section{References}

Bevan MW, Flavell RB, Chilton MD (1983) A chimeric antibioticresistance gene as a selectable marker for plant-cell transformation. Nature 304:184-187. doi:10.1038/304184a0

Brookes G, Barfoot P (2013) The global income and production effects of genetically modified (GM) crops 1996-2011. GM Crops Food 1:74-83. doi:10.4161/gmcr.24176

Fraley RT, Rogers SG, Horsch RB, Sanders PR, Flick JS, Adams SP, Bittner ML, Brand LA, Fink CL, Fry JS, Galluppi GR, Goldberg SB, Hoffmann NL, Woo SC (1983) Expression of bacterial genes in plant cells. Proc Natl Acad Sci USA 80:4803-4807

Glover BJ, Martin C (2012) Anthocyanins. Curr Biol 22:147-150. doi:10.1016/j.cub.2012.01.021

Herrera-Estrella L, De Block M, Messens E, Hernalsteens J-P, Van Montagu M, Schell J (1983) Chimeric genes as dominant selectable markers in plant-cells. EMBO J 2:987-995

James C (2012) Global status of commercialized biotech/GM Crops: 2012. ISAAA Brief No. 44. ISAAA, Ithaca, NY

Joensuu JJ, Niklander-Teeri V, Brandle JE (2008) Transgenic plants for animal health: plant-made vaccine antigens for animal infectious disease control. Phytochem Rev 7:553-577

Martin C, Butelli E, Petroni K, Tonelli C (2011) How can research on plants contribute to promoting human health? Plant Cell 23: 1685-1699. doi:10.1105/tpc.111.083279

Tang G, Hu Y, Yin HA, Wang Y, Dallal GE, Grusak MA, Russell RM (2012) $\beta$-Carotene in golden rice is as good as $\beta$-carotene in oil at providing vitamin A to children. Am J Clin Nutr 96:658-664. doi:10.3945/ajen.111.030775

Vasil IK (2008) A history of plant biotechnology: from the cell theory of Schleiden and Schwann to biotech crops. Plant Cell Rep 27:1432-1440. doi:10.1007/s00299-008-0571-4

Yusibov V, Streatfield SJ, Kushnir N (2011) Clinical development of plant-produced recombinant pharmaceuticals: vaccines, antibodies and beyond. Hum Vaccines 7:313-321 